Abstract 50 Table 1 Life's simple 7 scoring chart

\begin{tabular}{|c|c|c|c|}
\hline Component & Ideal (2 Poins) & Intermeciate (1 Point) & Poor (0 Points) \\
\hline Smoking & Never or former $>1$ year & Former $\leq 1$ year & Current \\
\hline Healtty diet score* & 4 to 5 points & 2 to 3 points & 0 to 1 points \\
\hline Physical activily ${ }^{\dagger}$ & $\begin{array}{l}\geq 4 \text { bouts per week of intense physical } \\
\text { activity sufficicent to work up a sweat }\end{array}$ & $\begin{array}{l}\text { t to } 3 \text { bouts per week of interse physical } \\
\text { activity sufficient to work up a sweat }\end{array}$ & $\begin{array}{l}\text { No intense physical activity } \\
\text { sufficient to work up a sweat }\end{array}$ \\
\hline Body mass index & $<25 \mathrm{~kg} / \mathrm{m}^{2}$ & 25 to $29.9 \mathrm{~kg} / \mathrm{m}^{2}$ & $\geq 30 \mathrm{~kg} / \mathrm{m}^{2}$ \\
\hline Blood pressure & $<120 / 800 \mathrm{~mm}$ Hg untreated & $\begin{array}{l}\text { SBP } 120 \text { to } 139 \text { or DBP } 80 \text { to } 89 \mathrm{~mm} \mathrm{Hg} \\
\text { or treater to ideal levell }\end{array}$ & $S B P \geq 140$ or $D B P \geq 90 \mathrm{~mm} \mathrm{Hg}$ \\
\hline Total cholesterol & $<5.18 \mathrm{mmoll}$ (<200 mg/dL) untreated & $\begin{array}{l}5.18 \text { to } 6.19 \mathrm{mmoll} \text { (200 to } 239 \mathrm{mg} / \mathrm{cl}) \\
\text { or treated to id ideal level }\end{array}$ & $\geq 6.22 \mathrm{mmolL}$ (2240 mg/dL) \\
\hline Fasting glucose & $<5.55 \mathrm{mmoll}$ < <100 mg/dL) untreated & $\begin{array}{l}5.55 \text { to } 6.94 \mathrm{mmoll} \text { (100 to } 125 \mathrm{mg} / \mathrm{cl} \text { ) } \\
\text { of treated to ideal level }\end{array}$ & $\geq 6.99 \mathrm{mmolL} \geq 126 \mathrm{mg} / \mathrm{dL} L$ \\
\hline
\end{tabular}

(Table adapted from REGARDS study and AHA guidelines)

Guide:

Ask the patient on an average day what is their intake of each of the followin

*Healthy diet score $=(1)$ Fruits and vegetables $\geq 4.5$ cups/day. (2) Fish $\geq 200$ g ( 2 medium portions)per week (3) fibre rich whole grains (kamut, teff, pearl barley, quinoa, whole-wheat pasta, buckwheat, oatmeal, whole wheat bread, and brown rice) $3 \times 30$ gram (1 ounce) portions/day. (4) salt $<1500 \mathrm{mg} /$ day $(2 / 3$ a teaspoon), (5) sugar sweetened beverages ( 1 litre/week).

tPhysical activity is measured by asking the question "How many times per week do you undertake moderate intensity of physical activity lasting 30 minutes, enough to work up a sweat, where you may be able to talk, but not sing?"

For blood pressure where possible, please use home measurements or ABPM if performed. For non-diabetic patients, assume fasting glucose is normal unless $\mathrm{HbA1c}$ is elevated.

Total score.

14

\begin{tabular}{|c|c|c|}
\hline \multicolumn{3}{|c|}{$\begin{array}{c}\text { Life's Simple } 7 \text { and Their Frequencies in a Pre- } \\
\text { Clinical Heart Failure Population }\end{array}$} \\
\hline & & Percentage \\
\hline \multirow[t]{3}{*}{ Body Mass Index Score } & 0 & $39.0 \%$ \\
\hline & 1 & $44.2 \%$ \\
\hline & 2 & $16.9 \%$ \\
\hline \multirow[t]{3}{*}{ Blood Pressure Score } & 0 & $29.7 \%$ \\
\hline & 1 & $63.4 \%$ \\
\hline & 2 & $7.0 \%$ \\
\hline \multirow[t]{3}{*}{ Diet Score } & 0 & $5.2 \%$ \\
\hline & 1 & $48.3 \%$ \\
\hline & 2 & $46.5 \%$ \\
\hline \multirow[t]{3}{*}{ Glucose Score } & 0 & $29.1 \%$ \\
\hline & 1 & $32.6 \%$ \\
\hline & 2 & $38.4 \%$ \\
\hline \multirow[t]{3}{*}{ Hypercholesterolaemia Score } & 0 & $4.7 \%$ \\
\hline & 1 & $77.9 \%$ \\
\hline & 2 & $17.4 \%$ \\
\hline \multirow[t]{3}{*}{ Physical Activity Score } & 0 & $45.9 \%$ \\
\hline & 1 & $18.2 \%$ \\
\hline & 2 & $35.9 \%$ \\
\hline \multirow[t]{3}{*}{ Smoking Score } & 0 & $9.9 \%$ \\
\hline & 1 & $2.9 \%$ \\
\hline & 2 & $87.1 \%$ \\
\hline
\end{tabular}

smoking $(87.1 \%)$ and a healthy diet $(46.5 \%)$ were the most common healthy behaviours. Table 1 demonstrates each LS7 frequency in the population. The only statistically significant correlation was a higher BNP level with a lower BMI $(\mathrm{P}<0.05)$ (figure 2a). The other LS7 behaviours (diet, PA, smoking status, blood pressure, glucose and cholesterol ffigure $2 \mathrm{~b}-\mathrm{g}\}$ ) as well as a composite (figure $2 \mathrm{~h}$ ) demonstrated no significant correlation with BNP.
Conclusion Analysis shows that LS7 scores vary widely in those at risk for HF. The areas of prime concern are lack of adherence to physical activity, blood pressure control and maintaining a healthy weight. The failure to show an association between LS7 and BNP might reflect the divergent impact of components of this score on BNP. For example, increasing $\mathrm{BMI}$ with reduction in BNP and poor BP score with increasing BNP. This analysis provides two important pieces of information in our effort to provide an overarching approach to HF prevention, firstly, the need to place an emphasis on BP management and a healthy weight but also to target physical activity levels. Secondly, the lack of association between BNP and LS7 score indicates that while BNP remains the ultimate risk indicator, that it does not appear to reflect this aspect of care.

\section{APPROPRIATENESS OF TROPONIN TESTING IN PATIENTS ADMITTED MEDICALLY THOROUGH THE EMERGENCY DEPARTMENT}

K Yadav, E Saghie, N Copty, M Strader, P O'Callaghan. University Hospital Waterford, Ireland

\subsection{6/heartjnl-2021-ICS.51}

Acute myocardial infarction (AMI) is defined as cardiomyocyte necrosis in the clinical setting consistent with myocardial ischaemia. High sensitivity cardiac troponin (hs-cTn) is the gold standard for measuring myocardial cell injury. However, inappropriate hs-cTn testing as part of routine bloods at the triage level in the emergency department (ED) can lead to unnecessary serial testing and further interventions such as invasive coronary angiography. Furthermore, the financial burden and impact on laboratory services must be taken into consideration. Each hs-cTn test costs approximately six euros. Our primary aim was to identify if hs-cTn requests sent through the ED comply with our local guidelines by analysing the subset of patients admitted medically.

We conducted a retrospective audit at University Hospital Waterford (UHW) looking at hs-cTn requests over a random two week period analysing the indication and the diagnostic 
University Hospital Waterford High-Sensitivity Cardiac Troponin T Guideline

\begin{tabular}{|c|c|}
\hline $\begin{array}{l}\text { Troponin Tests should be performed on the following group of } \\
\text { patients provided they fit the criteria for performing the test - } \\
\text { presenting symptoms occurred at least } 2 \text { hours prior to } \\
\text { the test being performed }\end{array}$ & $\begin{array}{l}\text { Category of Patients who } \\
\text { Do not require Troponin Test } \\
\text { to be performed or repeated. }\end{array}$ \\
\hline $\begin{array}{l}\text { Patients who present with Chest Pain / Discomfort } \\
\text { which must have been present without relief for at } \\
\text { least } 30 \text { minutes. } \\
\text { Patients who present with Acute SOB, Collapse of } \\
\text { unknown origin. }\end{array}$ & $\begin{array}{l}\text { Patients who present and are diagnosed with } \\
\text { STEMI and who are treated promptly either with } \\
\text { Thrombolysis or fastracked to Cath Lab for rescue } \\
\text { Angiogram }+1 \text { - PCI DO NOT require Troponin } \\
\text { T tests unless requested by Cardiologist }\end{array}$ \\
\hline $\begin{array}{l}\text { Patients with Diabetes who present with history of } \\
\text { weakness, SOB collapse without or without chest } \\
\text { pain / discomfort. } \\
\text { Use when ECG Unclear to Confirm or Exclude } \\
\text { M.I. in above cases. }\end{array}$ & $\begin{array}{l}\text { Patients who have Troponin Test result }>2000 \mathrm{ng} / \mathrm{l} \\
\text { DO NOT NEED repeat test - Refer to Cath Lab / } \\
\text { Cardiology Team }\end{array}$ \\
\hline$>$ Arrthymias - Fast A Fib, & \\
\hline $\begin{array}{l}\text { Patients with ischaemic ECG changes, (peaked T's. } \\
\text { flattened T's, Inverted T's, ST Segment depression } \\
\text { with or without T inversion) } \\
>\text { New or presumed New LBBB on ECG }\end{array}$ & $\begin{array}{l}\text { Patients who do not have risk factors for CAD with } \\
\text { test result of }<14 \text { ng/l, do not need repeat testing } \\
\text { provided the initial test was performed within the } \\
\text { specified time frame of } 2 \text { hours post presenting } \\
\text { complaint. }\end{array}$ \\
\hline $\begin{array}{l}\text { Patients with result of }>14-<52 \text { must have test } \\
\text { repeated using fresh sample } 2 \text { hours after the first } \\
\text { test was done. }\end{array}$ & \\
\hline $\begin{array}{ll}\text { endan Mc Cann } & \text { Dr. Pat O' Callaghan } \\
\operatorname{tant} \text { in Emergency Medicine } & \text { Lead Consultant Cardiologist }\end{array}$ & $\begin{array}{l}\text { Seamus Cotter } \\
\text { Chief Medical Scientist }\end{array}$ \\
\hline
\end{tabular}

Abstract 51 Figure 2 UHW local guideline

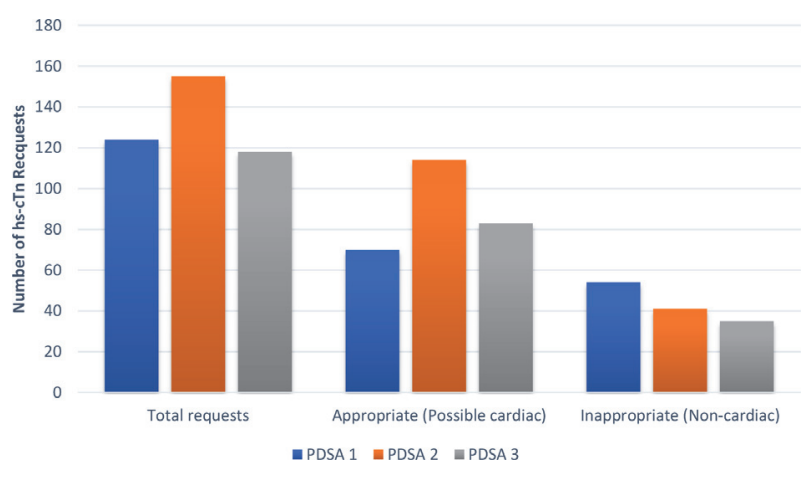

Abstract 51 Figure 1 Illustration of trend of troponin requests

\begin{tabular}{llll}
$\begin{array}{l}\text { Abstract } \\
\text { cycles }\end{array}$ & & \\
\hline & TOTAL & APPROPRIATE (POSSIBLE & Summary of troponin requests over three \\
& REQUESTS & CARDIAC) & $\begin{array}{l}\text { INAPPROPRIATE (NON- } \\
\text { CARDIAC) }\end{array}$ \\
\hline PDSA1 & 124 & $70(56 \%)$ & $54(44 \%)$ \\
PDSA2 & 155 & $114(74 \%)$ & $41(26 \%)$ \\
PDSA3 & 118 & $83(70 \%)$ & $35(30 \%)$ \\
\hline
\end{tabular}

yield. It was observed that a large percentage of hs-cTn were ordered inappropriately. Out of the total $(n=124), 56 \%(n=70)$ requests were appropriate and $44 \%(n=54)$ were inappropriate. In the ED setting, most of the requests were ordered as part of routine bloods during triage. We identified areas where interventions could be made for quality improvement. We highlighted the findings of our audit to the Triage nurses and ED medical staff. A poster of local hospital guidelines was hung in Triage rooms, routine testing of hs-cTn before clinician assessment was discouraged, and it was suggested that a hscTn could be easily added on after clinical assessment.
We repeated the audit after 1-2 months using the same methods during data collection. After PDSA cycle $2(n=155)$, $74 \% \quad(n=114)$ requests were appropriately sent and $26 \%$ $(n=41)$ were inappropriate. Following Cycle 2, we re-educated and stressed the importance of following hs-cTn guidelines. Finally, we performed a third cycle over 2 weeks analysing hs-cTn ordering and indications. In PDSA cycle $3 \quad(n=118)$, $70 \% \quad(n=83)$ of the requests were appropriate and $30 \%$ $(n=35)$ were inappropriate. A quantifiable improvement was noted on repeat audit cycles with a further potential of reducing inappropriate requests.

Hs-cTn is a gold standard test in diagnosing Acute Coronary Syndrome (ACS). However, one has to be aware of the varying clinical circumstances in which it can be elevated. HscTn testing is only indicated when ACS is clinically suspected. Appropriate use of ESC and local guidelines with hs-cTn requests can lead to a significant reduction in admissions, workload and financial burden.

\section{LONG-TERM CLINICAL OUTCOMES AFTER DRUG ELUTING STENT IMPLANTATION WITH AND WITHOUT STENT OVERLAP}

${ }^{1} \mathrm{JJ}$ Coughlan, ${ }^{2} \mathrm{~A}$ Aytekin, ${ }^{2} \mathrm{~T}$ Koch, ${ }^{2} \mathrm{~J}$ Wiebe, ${ }^{2} \mathrm{~T}$ Lenz, ${ }^{2} \mathrm{~S}$ Cassese, ${ }^{2} \mathrm{M}$ Joner, ${ }^{3} \mathrm{~T}$ Koppara, ${ }^{2} \mathrm{E}$ Xhepa, ${ }^{3} \mathrm{~T}$ Ibrahim, ${ }^{2} \mathrm{M}$ Fusaro, ${ }^{3} \mathrm{KL}$ Laugwitz, ${ }^{2} \mathrm{H}$ Schunkert, ${ }^{2} \mathrm{~A}$ Kastrati, ${ }^{2} \mathrm{~S}$ Kufner. ${ }^{1}$ German Heart Centre Munich, Germany; ${ }^{2}$ Klinik für Herz- und Kreislauferkrankungen, Deutsches Herzzentrum München, Germany, ${ }^{3}$ Klinikum rechts der Isar, Munich, Germany

\subsection{6/heartjnl-2021-ICS.52}

Aims The aim of this study was to investigate the impact of drug eluting stent (DES) overlap on clinical outcomes after percutaneous coronary intervention (PCI).

Methods We analyzed the angiographic and clinical outcomes of 5,605 patients treated with DES in the setting of the ISAR-TEST 4 and ISAR-TEST 5 trials according to the presence or absence of stent overlap at index PCI. The 10 year clinical endpoints assessed were all-cause death, myocardial 